\title{
Educating Student Managerial Leaders: What Critical Behaviors Should Be Developed?
}

\author{
Tim O. Peterson (Corresponding author) \\ College of Business, North Dakota State University \\ $8112^{\text {nd }}$ Avenue North, Fargo, North Dakota 58108, United States \\ Tel: 1-701-231-7061Ｅ-mail: tim.o.peterson@ndsu.edu
}

Claudette M. Peterson

School of Education, North Dakota State University

PO Box 6050, Fargo, North Dakota 58198, United State

Tel: 1-701-231-7085Ｅ-mail: claudette.peterson@ndsu.edu

Received: May 15, 2015 Accepted: June 18, 2015 Published: June 19, 2015

doi:10.5296/jei.v1i1.7612ＵRL: http://dx.doi.org/10.5296/jei.v1i1.7612

\begin{abstract}
If we want student leaders to be prepared for the workforce, we need to develop their managerial leadership behaviors while they are in school. Peterson and Peterson (2012) identified a set of critical managerial leadership behaviors that should be taught while students are in college. However, the empirical work was done at a single Southwest university. This manuscript replicates the Peterson and Peterson study at a Midwest university. In addition, it extends the research by having the subjects rank order the managerial leadership behaviors they initially selected. The results identify a set of managerial leadership behaviors that could be taught and practiced by student leaders while they are still in a university setting. These students could then enter the workforce prepared to lead and manage.
\end{abstract}

Keywords: Student leader, Managerial leadership, Critical managerial behaviors, Leadership education

\section{Introduction}

Burchard (2009) posited that without an understanding of leadership, students cannot become effective agents of positive change in their own lives, in the organizations in which they serve 
or work, or in their communities. Fairholm (1998) argued that understanding the role and functions of leadership is the most important cognitive process of young people. It would explain why we have books like Deeper Learning in Leadership: Helping College Students Find the Potential Within (Roberts, 2007), The Student Leadership Challenge (Kouzes \& Posner, 2014), and Exploring Leadership: For College Students Who Want to Make a Difference (Komives, Lucas, \& McMahon, 2013). Van Velsor, McCauley, and Moxley (1998) defined leadership development as the expansion of a person's capacity to be effective in a leadership role or process. Student affairs officers sometimes claim that students who participate in student organizations develop leadership abilities and gain experience. However, recent research demonstrated that there may be less development than expected (Roberts, 2007). Management educators might consider what leadership skills to focus on to help student leaders develop those skills while in college and transfer them to the workforce when they begin their careers.

\section{Student Managerial Leadership}

T. O. Peterson and C. M. Peterson (2012) noted that the term student leader is used rather than student manager to describe students who hold an official role such as president, vice president, or treasurer in a student organization. In order to help student organizations fulfill their missions and accomplish their goals, student leaders must both manage and lead. As separate skills, leadership and management are necessary, but not sufficient. If student leaders only know how to exhibit one of those skills, they are likely to fail. It would be more accurate to think of these students as student managerial leaders.

All student leaders have responsibility for achieving the objectives of the organization. This requires both management and leadership ability. T. O. Peterson and C. M. Peterson (2010) defined student managerial leaders as persons who hold an official positions in organizations, have legitimate authority such that they have decision-making power over organizational resources, are held accountable for achieving the organizations' objectives, and attempt to influence others through leadership behaviors. Peterson and Peterson's initial research identified eight critical managerial leadership behaviors (see Table 1) from a list of 25 managerial leadership behaviors. 
Table 1. Frequency and percent of participants who identified each behavior as a critical managerial leadership behaviors $(n=720)$

\begin{tabular}{|l|l|l|}
\hline Managerial Leadership Behavior & Frequency & Percent \\
\hline Is friendly and considerate & 452 & 62.8 \\
\hline Stimulates enthusiasm (Inspires) & 423 & 58.8 \\
\hline Builds team & 447 & 62.1 \\
\hline Delegates authority & 383 & 53.2 \\
\hline Informs about responsibilities & 376 & 52.2 \\
\hline Keeps employees informed & 362 & 50.3 \\
\hline Takes the initiative (Solves problems) & 455 & 63.2 \\
\hline Builds trust (Is credible) & 545 & 75.7 \\
\hline
\end{tabular}

Note. Adapted from "What managerial leadership behaviors do student managerial leaders need? An empirical study of student organizational members" by T. O. Peterson and C. M Peterson (2012).

In that earlier study, the subject pool consisted of members of student organizations rather than the student leaders themselves. The research also reported on how past research on managerial leadership in other non-academic settings aligns with their findings. This table is reproduced in Table 2 .

Table 2. Summary of the four studies on managerial leadership behaviors

\begin{tabular}{|l|l|l|l|l|}
\hline Managerial Leadership Behavior & $\begin{array}{l}\text { Southwest } \\
\text { University Study }\end{array}$ & $\begin{array}{l}\text { Military } \\
\text { Study }\end{array}$ & $\begin{array}{l}\text { For-profit } \\
\text { Study }\end{array}$ & $\begin{array}{l}\text { Not-for-profit } \\
\text { Study }\end{array}$ \\
\hline Is friendly and considerate & $\mathrm{X}$ & $\mathrm{X}$ & $\mathrm{X}$ & $\mathrm{X}$ \\
\hline Stimulates enthusiasm (Inspires) & $\mathrm{X}$ & $\mathrm{X}$ & $\mathrm{X}$ & $\mathrm{X}$ \\
\hline Builds team & $\mathrm{X}$ & & $\mathrm{X}$ & $\mathrm{X}$ \\
\hline Delegates authority & $\mathrm{X}$ & & $\mathrm{X}$ & \\
\hline Informs about responsibilities & $\mathrm{X}$ & $\mathrm{X}$ & $\mathrm{X}$ & $\mathrm{X}$ \\
\hline Keeps employees informed & $\mathrm{X}$ & & $\mathrm{X}$ & $\mathrm{X}$ \\
\hline Takes the initiative (Solves problems) & $\mathrm{X}$ & $\mathrm{X}$ & $\mathrm{X}$ & $\mathrm{X}$ \\
\hline Builds trust (Is credible) & $\mathrm{X}$ & & $\mathrm{X}$ & $\mathrm{X}$ \\
\hline
\end{tabular}

Note. Adapted from "What managerial leadership behaviors do student managerial leaders need? An empirical study of student organizational members" by T. O. Peterson and C. M. Peterson (2012). 
In the discussion portion of the T. O. Peterson and C. M. Peterson (2012) article, one reported limitation of the study was that all the subjects came from one Southwestern university. They suggested that another sample be collected and analyzed at a different university. In addition, they pondered whether asking the subjects to also rank the behaviors might provide additional insight to the findings. The purpose of this manuscript is to replicate the earlier study and then extend that earlier study by having the subjects rank the chosen behaviors.

\section{Method}

\subsection{Participants}

The participants in this study were 720 student constituents from 46 different student organizations on a large Midwest university campus. A sample of 720 subjects was recruited by snowball sampling (Creswell, 2005; Gay \& Airasian, 2000) to provide a sample similar to the first study. To take part in the study, each participant had to be engaged in any student organization that was recognized by the university, but not be an officer or hold some other official position within the student organization. Each subject was asked to complete a one-page instrument on the topic of managerial leadership and then to answer a few demographic questions. The subjects were not offered extra credit for their involvement in the study.

\subsection{Measure}

We used the Peterson Managerial Leadership Instrument which has been used in the studies conducted by Peterson and Van Fleet (2003, 2008), T. O. Peterson and C. M. Peterson (2010, 2012), and Peterson, Beard, and Van Fleet (2012). It consists of 25 managerial leadership behaviors which have been confirmed to be important to managerial leadership effectiveness (Kouzes \& Posner, 2003; Yukl \& Nemeroff, 1979; Yukl, Wall, \& Lepsinger, 1990).

The instrument lists the twenty-five managerial leadership behaviors which had been identified as important in previous research. An example of the instrument is located in the Appendix. The participants were asked to complete a two-step process. First, they were asked to select $10(40 \%)$ of the 25 behaviors that they believed were critical for the organizations student leaders to exhibit in order to achieve the purpose of the student organization. Second, they were then asked to rank order by importance the 10 behaviors that they identified as critical, with 1 being the most critical and 10 being the least critical. Peterson and Peterson (2012) commented that an earlier reviewer had suggested this as a possible enhancement. The instructions at the top of the instrument said:

Below are 25 behaviors a student leader could exhibit on any given day. All of these behaviors are important in order to achieve the organization's purpose. First pick the ten (10) behaviors that you think are most critical for a student leader to achieve your organization's purpose. Next please rank from 1 (highest) to 10 (lowest) these ten (10) behaviors.

Finally, participants were asked for demographic information such as age, gender, classification, academic major and the name of the student organization in which they were a member. 


\subsection{Procedure}

Multiple copies of the instrument were distributed to students in a leadership class as part of a class assignment. Each student in the leadership class was asked to obtain 20 responses by passing out the survey to members in one or more student organizations. The students brought the completed surveys to class and spent time with the instructor exploring the data from this action research project in order to explore the critical managerial leadership behaviors desired by organizational student constituents.

\subsection{Analysis}

The statistical analysis was conducted using SPSS. First we produced descriptive and exploratory data analyses to examine the data for outliers, unusual values, and peculiarities in the data set. Any suspicious data was checked against the original documents and any necessary corrections were made.

After the exploratory examination, we decided to first examine whether the Midwestern and Southwest samples were similar based on demographics. As the replication of the earlier study, we examined the frequency of selection for each of the managerial leadership behaviors in the Midwest sample. Next, we used the inference about a proportion as presented in Ott (1984) to identify the critical managerial leadership behaviors. Finally, to expand the research to include the rankings, we conducted a series of t-tests on the managerial leadership behaviors assuming we did not know the results of the earlier proportion study.

\section{Results}

The mean age of the subjects from the Midwest study was 19.5 years with a range from 18 to 40 years of age. In the previous sample from the Southwestern university, the mean age was 20 years with a range from 17 to 29 years. It would appear at a glance that the two samples have similar mean ages. However an independent sample t-test $\left.\left\{\mathrm{t}_{(1429)}=7.34, \mathrm{p}<.05, \mathrm{r}=.19\right)\right\}$ indicated that the mean ages from the two samples were statistically different from each other. Students represented 90 different majors in the Midwest sample compared with 91 majors in the Southwest sample. There were 46 different student organizations represented in the Midwest sample compared with 41 in the Southwest sample.

Table 3 presents other demographic comparisons. There was a more equal division by gender in the Midwest sample, while females outnumbered males approximately 2 to 1 in the earlier Southwest sample. Examination of the student classification (e.g., freshman, sophomore, etc.) indicated that on the whole, the participants in the Midwest study are at an earlier stage of their post-secondary education. It seems clear that not only are the two samples drawn from two different universities but that the demographics are different. Therefore, this should provide for a strong test of both the importance of all 25 behaviors and the identification of the critical managerial leadership behaviors. 
Table 3. Demographics comparisons for the two independent samples

\begin{tabular}{|l|l|l|}
\hline Demographics & Southwest & Midwest \\
\hline Gender & & \\
\hline Males & $232(32 \%)$ & $375(52 \%)$ \\
\hline Females & $480(67 \%)$ & $345(48 \%)$ \\
\hline Missing data & $8(1 \%)$ & $0(0 \%)$ \\
\hline Total Participants & $\mathbf{7 2 0}(\mathbf{1 0 0} \%)$ & $\mathbf{7 2 0}(\mathbf{1 0 0} \%)$ \\
\hline Student Classification of Participants & & \\
\hline Freshmen & $165(23 \%)$ & $321(45 \%)$ \\
\hline Sophomores & $211(29 \%)$ & $166(23 \%)$ \\
\hline Juniors & $204(28 \%)$ & $137(19 \%)$ \\
\hline Seniors & $127(18 \%)$ & $88(12 \%)$ \\
\hline Fifth year seniors & $7(1 \%)$ & $7(1 \%)$ \\
\hline Missing data & $6(1 \%)$ & $1(0 \%)$ \\
\hline Total Participants & $\mathbf{7 2 0}(\mathbf{1 0 0} \%)$ & $\mathbf{7 2 0}(\mathbf{1 0 0} \%)$ \\
\hline
\end{tabular}

Table 4 reports frequency scores for each managerial leadership behavior in the Midwest study. The table shows that there are positive values in all cells. This result supports the contention that all of the 25 managerial leadership behaviors are important to at least some of the participants. If the subjects felt all of the behaviors were equally important, we would have found the same number of marks by each behavior [(720 subjects $\times 10$ marks per subject) $/ 25$ behaviors $=288$ marks by each behavior]. If this were the case the mean percentage of participants who identified each behavior as critical would be $40 \%$ (288/720). Examination of Table 4 shows that this is not true. Clearly some behaviors such as Builds trust (Is credible) have more marks (523) and a higher percentage (72.6\%) and other behaviors such as Identifies and enforces the norms have many fewer than 288 marks and a lower percentage rate (78 marks; 10.8\%). Therefore, there are managerial leadership behaviors that are identified as more critical than others. 


\section{IInstituthenk}

Journal of Educational Issues

ISSN 2377-2263

2015, Vol. 1, No. 1

Table 4. Frequency and percent of participants who identified each behavior as a critical managerial leadership behaviors in the Midwest study $(\mathrm{n}=720)$

\begin{tabular}{|c|c|c|}
\hline Managerial Leadership Behavior & Frequency & Percent \\
\hline Emphasizes performance & 279 & 38.8 \\
\hline Is friendly and considerate & 506 & 70.3 \\
\hline Stimulates enthusiasm (Inspires) & 392 & 54.4 \\
\hline Provides praise and recognition & 316 & 43.9 \\
\hline Rewards performance (Motivates) & 193 & 26.8 \\
\hline Builds team & 523 & 72.6 \\
\hline Consults employees & 214 & 29.7 \\
\hline Delegates authority & 341 & 47.4 \\
\hline Informs about responsibilities & 375 & 52.1 \\
\hline Emphasizes goals & 253 & 35.1 \\
\hline Measures progress & 225 & 31.3 \\
\hline Determines training needs & 101 & 14.0 \\
\hline Keeps employees informed & 393 & 54.6 \\
\hline Takes the initiative (Solves problems) & 460 & 63.9 \\
\hline Coordinates the work & 224 & 31.1 \\
\hline Obtains resources & 177 & 24.6 \\
\hline Eliminates obstacles & 158 & 21.9 \\
\hline Establishes contacts & 206 & 28.6 \\
\hline Gets employees to be friendly with each other & 296 & 41.1 \\
\hline Restrains employees from arguing & 138 & 19.2 \\
\hline Disciplines & 189 & 26.3 \\
\hline Plans & 300 & 41.7 \\
\hline Creates a clear and compelling direction & 340 & 47.2 \\
\hline Identifies and enforces the norms & 78 & 10.8 \\
\hline Builds trust (Is credible) & 523 & 72.6 \\
\hline
\end{tabular}

Note. The items are listed in the order in which they appear on the instrument.

Just as T. O. Peterson and C. M. Peterson (2012) did in their earlier study, we calculated an upper confidence interval equal to three standard deviations using Ott's (1984) formula for 
determining confidence coefficients for proportions. The average proportion as stated earlier is 40 percent. The standard error for this proportion is calculated as $\sqrt{ }[\pi(1-\pi) / \mathrm{n}]$ or $\sqrt{ }[.40(.60) / 720]$ which equals .01826 . With a Z.0005 value of 3.291 , the test value $(.40+(3.291$ $\mathrm{x} .01826)$ ) was calculated at $46 \%$. In the earlier study, Peterson and Peterson (2012) rounded the average proportion to $50 \%$ in order to be conservative. Rounding to $50 \%$ was also done in the earlier Kouzes and Posner credibility study (1993). As in the earlier studies, we rounded this value to $50 \%$ to ensure that we only included the truly critical behaviors. Therefore, all frequency percent values that are equal to or exceed $50 \%$ are considered critical. Table 5 shows only those seven managerial leadership behaviors that meet this criterion.

Table 5. Frequency and percent of the critical managerial leadership behaviors in the Midwest study $(\mathrm{n}=720)$

\begin{tabular}{|l|l|l|}
\hline Managerial Leadership Behavior & Frequency & Percent \\
\hline Builds team & 523 & 72.6 \\
\hline Builds trust (Is credible) & 523 & 72.6 \\
\hline Is friendly and considerate & 506 & 70.3 \\
\hline Takes the initiative (Solves problems) & 460 & 63.9 \\
\hline Keeps employees informed & 393 & 54.6 \\
\hline Stimulates enthusiasm (Inspires) & 392 & 54.4 \\
\hline Informs about responsibilities & 375 & 52.1 \\
\hline
\end{tabular}

Next we extended this research by examining the rankings of the managerial leadership behaviors. In the original instructions, participants were asked to rank the most critical behavior as 1 and the least critical of their critical behaviors as 10 . We began by recoding those ranking scores assigned by the participants so that the behavior that was ranked the highest received a score of ten and the behavior ranked lowest received a score of one for purposes of analysis. Those behaviors which did not receive a ranking by a participant were coded as zero. So for the full set of 25 behaviors, a single subject would have ten behaviors ranked from 1 to 10 and fifteen zeros or a mean score of 2.2, so, the target value was set at 2.2. Table 6 reports the results of the ranking analysis. Those in bold were found to be significant at the $\mathrm{p}<.05$ level using a one-tail t-test comparing them to the target value. We also calculated the effect size using Cohen's $d$ (1988) which is also reported in Table 6. So while there were seven critical behaviors identified when participants were just asked to identify critical behaviors, there were nine behaviors that were identified as critical when the behaviors were ranked. The nine behaviors overlap with the seven checked behaviors in this study and eight checked behaviors from the earlier studies. The ninth behavior which was identified is creates a clear and compelling direction. 
Table 6. One tail $\mathrm{t}$-tests for the ranking of managerial leadership behaviors in the Midwest study (Target Value $=2.2, \mathrm{~N}=720, d f=719, \mathrm{p}<.05)$

\begin{tabular}{|c|c|c|c|c|}
\hline Managerial Leadership Behavior & Mean & SD & t-value & Effect Size \\
\hline Emphasizes performance & 2.28 & 3.43 & .62 & N/A \\
\hline Is friendly and considerate & 4.56 & 3.88 & 16.36 & .61 \\
\hline Stimulates enthusiasm (Inspires) & 3.18 & 3.58 & 7.30 & .27 \\
\hline Provides praise and recognition & 2.17 & 3.05 & -.28 & $\mathrm{~N} / \mathrm{A}$ \\
\hline Rewards performance (Motivates) & 1.42 & 2.76 & -7.60 & N/A \\
\hline Builds team & 4.69 & 3.75 & 17.84 & .66 \\
\hline Consults employees & 1.538 & 2.78 & -6.50 & $\mathrm{~N} / \mathrm{A}$ \\
\hline Delegates authority & 2.61 & 3.36 & 3.30 & .12 \\
\hline Informs about responsibilities & 2.75 & 3.27 & 4.53 & .17 \\
\hline Emphasizes goals & 1.91 & 3.03 & -2.53 & N/A \\
\hline Measures progress & 1.51 & 2.69 & -6.89 & $\mathrm{~N} / \mathrm{A}$ \\
\hline Determines training needs & .61 & 1.81 & -23.63 & N/A \\
\hline Keeps employees informed & 2.98 & 3.38 & 6.18 & .23 \\
\hline Takes the initiative (Solves problems) & 3.67 & 3.57 & 11.04 & .41 \\
\hline Coordinates the work & 1.53 & 2.72 & -6.62 & N/A \\
\hline Obtains resources & 1.17 & 2.45 & -11.25 & N/A \\
\hline Eliminates obstacles & 1.07 & 2.37 & -12.82 & N/A \\
\hline Establishes contacts & 1.27 & 2.42 & -10.37 & N/A \\
\hline Gets employees to be friendly with each other & 1.97 & 2.94 & -2.10 & $\mathrm{~N} / \mathrm{A}$ \\
\hline Restrains employees from arguing & .86 & 2.06 & -17.50 & N/A \\
\hline Disciplines & 1.21 & 2.46 & -10.84 & N/A \\
\hline Plans & 2.13 & 3.06 & -.58 & N/A \\
\hline Creates a clear and compelling direction & 2.75 & 3.54 & 4.20 & .16 \\
\hline Identifies and enforces the norms & .46 & 1.65 & -28.32 & N/A \\
\hline Builds trust (Is credible) & 4.70 & 3.91 & 17.13 & .64 \\
\hline
\end{tabular}

Cohen suggested the following subjective standards as a convention for interpreting $d$ in research in social and behavioral sciences: $d=.2$ could be considered a small effect size, $d$ $=.5$ could be considered a medium effect size, and $d=.8$ could be considered a large effect size (Lomax \& Hahs-Vaughn, 2012). As can be seen from Table 6, there are three behaviors with medium effect sizes, three with small effect sizes, and three behaviors with effect sizes 


\section{Macrothink

that are smaller than Cohen's proposed standards. This raises a question of whether these three behaviors while being statistically significant are also practically significant. This led to a post hoc analysis on these three behaviors.

\subsection{Post Hoc Analysis}

Two of the three behaviors (delegates authority and creates a clear and compelling direction) did not make the initial cut because not enough subjects marked them as critical. When you examine the frequencies of the rankings you find that very few subjects ranked these behaviors as their number one behavior (delegates authority had only 26 subjects rank it as the number one behavior and creates a clear and compelling direction had only 39 subjects rank it as the number one behavior). It is understandable why these two behaviors received a low effect size. On the other hand, the third behavior (informs about responsibilities) did make the initial cut during the marking process and was found to be significant during the ranking process. The lower effect size was again caused by a lower frequency of number one rankings but still should be considered within the critical set because of the percentage of subjects who marked it as critical and adequate rankings to make it significantly different from the target value.

\section{Discussion}

In a special issue of the Journal of Leadership Education, Middlebrooks and Allen (2009) argued that in the complex field of leadership, individuals need to identify what is important. They said that when educators are asked what their objective is in developing leaders the dominant answer is in building skills and how to execute those skills (Middlebrooks \& Allen, 2009). This manuscript coupled with past work makes a positive impact in the effort to determine what those skills should be. Since the seminal military leadership study (Yukl \& Van Fleet, 1982) did not include all of the managerial leadership behaviors currently being emphasized, we selected to drop the military study from our summary table. Table 7 shows how this replication study aligns with the previous Southwest student study, the for-profit study, and the not-for-profit study. The behaviors are now listed in order of criticality to the participants within the four studies. The behavior builds trust and is credible tied with the behavior builds team based on frequency of votes in the Midwest study. Therefore, these two managerial leadership behaviors are both listed in Table 7 as number one to indicate this tie. 
Table 7. Summary of the four studies on managerial leadership behaviors by criticality

\begin{tabular}{|l|l|l|l|l|}
\hline Managerial Leadership Behavior & $\begin{array}{l}\text { Current } \\
\text { Study }\end{array}$ & $\begin{array}{l}\text { Southwest } \\
\text { Study }\end{array}$ & $\begin{array}{l}\text { For-profit } \\
\text { Study }\end{array}$ & $\begin{array}{l}\text { Not-for-profit } \\
\text { Study }\end{array}$ \\
\hline Builds trust (Is credible) & $\mathbf{1}$ & $\mathbf{1}$ & $\mathbf{3}$ & $\mathbf{1}$ \\
\hline Builds team & $\mathbf{1}$ & $\mathbf{4}$ & $\mathbf{5}$ & $\mathbf{6}$ \\
\hline Is friendly and considerate & $\mathbf{3}$ & $\mathbf{3}$ & $\mathbf{4}$ & $\mathbf{2}$ \\
\hline Takes the initiative (Solves problems) & $\mathbf{4}$ & $\mathbf{2}$ & $\mathbf{2}$ & $\mathbf{4}$ \\
\hline Keeps employees informed & $\mathbf{5}$ & $\mathbf{8}$ & $\mathbf{1}$ & $\mathbf{3}$ \\
\hline Stimulates enthusiasm (Inspires) & $\mathbf{6}$ & $\mathbf{5}$ & $\mathbf{7}$ & $\mathbf{5}$ \\
\hline Informs about responsibilities & $\mathbf{7}$ & $\mathbf{7}$ & $\mathbf{8}$ & $\mathbf{7}$ \\
\hline Delegates authority & -- & $\mathbf{6}$ & $\mathbf{6}$ & -- \\
\hline
\end{tabular}

What can we learn from this table? First, student constituents, whether at the Midwest or the Southwest universities, want their student managerial leaders to build trust and be credible with them. This is consistent with Kouzes and Posner's (2003) findings over three decades. This behavior is also critical to both for-profit employees and not-for-profit staff members. The next six behaviors (builds team, is friendly and considerate, takes the initiative and solves problems, keeps employees informed, stimulates enthusiasm and inspires, and informs about responsibilities) are also identified as critical behaviors in all four contexts. These represent both managerial (e.g., keeps employees informed) and leadership (e.g., stimulates enthusiasm and inspires) behaviors.

The only behavior that is inconsistent among the four contexts is delegates authority. This behavior was not identified as a critical behavior of managerial leaders in the current Midwest study. In this study, 341 of the 720 participants (47.4\%) identified it as a critical behavior. This is actually $1.4 \%$ above the actual calculated upper confidence coefficient of $46 \%$ but does not meet the more conservative 50\% threshold. However, it would have required only 19 more of the 720 participants to identify it as a critical behavior to satisfy the rounded value of $50 \%$. This rounded value was used as a conservative measure to ensure that we only included truly critical behaviors.

Delegates authority was also not identified as a critical behavior in the not-for-profit study (Peterson \& Van Fleet, 2008). It may be noteworthy that the authors of that study in the not-for-profit context felt that delegating authority may not have been perceived as critical in that context where so many individuals are typically volunteers and the organizational structure or culture may not encourage or allow delegation. It was, however, identified as a critical behavior in the Southwest university study and the for-profit study.

The extension of the research to include ranking the behaviors shows a similar result to the earlier studies and the current replication. Ranking data is not available from the earlier studies. The ranking data that was collected at the suggestion of an earlier reviewer and 
presented previously in Table 6 shows that all seven managerial leadership behaviors met the threshold of being greater than the target value of 2.2. This means that when we view the ranked behavior data, all seven behaviors are both critical whether participants are ranking or simply identifying critical behaviors in the Midwest university study.

\section{Limitations and Future Research}

Like all studies this study has limitations. For example, both universities where studies have been done are public institutions. There may be a need to repeat the study at a private institution. In both of the university studies, we only asked student organizational members to identify the critical managerial leadership behaviors. It would be also interesting to ask the faculty advisors for these student organizations which managerial leadership behaviors they believe to be critical. It is possible that what the advisors expect out of the student managerial leaders and what the student members expect could be very different. This could put the student managerial leaders in a tense situation as they try to satisfy the expectations of two different sets of stakeholders. A follow-up to this study would be to ask student managerial leaders which behaviors they think organizational advisors find critical and which behaviors student members find critical. This would help identify if there is consistency for the student managerial leaders. In a future study, it might also be interesting to have participants rank all 25 behaviors and analyze those results for both important and critical managerial leadership behaviors.

\section{Implications}

In accordance with Van Velsor, McCauley, and Moxley's (1998) definition of leadership development as the expansion of a person's capacity to be effective in a leadership role or process, these findings, along with the earlier findings using the Managerial Leadership Instrument, should be a call to action for management educators and human resource development practitioners. The very managerial leadership behaviors that student constituents want from their student leaders are the same behaviors desired in the for-profit and not-for-profit organizations where these very students are headed. Although delegates authority did not quite make the cut to be identified as a critical behavior, it seems to us that a prudent management educator or a human resource development practitioner would include it in the development plan since it was significant at one of the academic settings and is significant for-profit managerial leaders.

Imagine a course at the freshmen level for nascent student leaders where they were introduced to these skills and allowed to practice them. Then imagine an advanced course where student leaders who are currently serving in leadership roles in student organizations could come together to discuss successes, advances, victories, challenges, hardships, mistakes, and failures. They would have a supportive learning environment in which to reflect and learn around these managerial leadership behaviors. By building such as a leadership development environment, student leaders would have a better opportunity to arrive in the workforce prepared to face the challenges of the future. 


\section{References}

Barrett, D. J. (2008). Leadership communication (2nd ed.). New York: McGraw-Hill Irwin.

Burchard, B. (2009). The student leadership guide (4th ed.). Garden City, NJ: Expert Academy.

Creswell, J. W. (2005). Educational research: Planning, conducting, and evaluating quantitative and qualitative research. Upper Saddle River, NJ: Pearson Education.

Fairholm, G. W. (1998). Perspectives on leadership: From the science of management to its spiritual heart. Westport, CT: Praeger.

Gay, L. R., \& Airasian, P. (2000). Educational research: Competencies for analysis and application (6th ed.). Upper Saddle River, NJ: Prentice-Hall.

Komives, S. R., Lucas, N., \& McMahon, T. R. (2013). Exploring leadership: For college students who want to make a difference (3rd ed.). San Francisco, CA: Jossey-Bass.

Kouzes, J. M., \& Posner, B. Z. (1993). Credibility: How leaders gain and lose it, why people demand it. San Francisco, CA: Jossey-Bass.

Kouzes, J. M., \& Posner, B. Z. (2003). Credibility: How leaders gain and lose it, why people demand it (Revised ed.). San Francisco, CA: Jossey-Bass.

Kouzes, J. M., \& Posner, B. Z. (2008). The student leadership challenge: Five practices for exemplary leaders (2nd ed.). San Francisco, CA: Jossey-Bass.

Lomas, R. G., \& Hahs-Vaugh, D. L. (2012). An introduction to statistical concepts (3rd ed.). New York, NY: Routledge.

Middlebrooks, A., \& Allen, S. J. (2009). Editors' introduction: The education of leadership. Journal of Leadership Education, 8(1), ix-xxiii. http://dx.doi.org/10.12806/V8/I1/C5

Ott, L. (1984). An introduction to statistical methods (2nd ed.). Boston, MA: Duxbury.

Peterson T. O., \& Peterson, C. M. (2010). An exploratory study of student leadership critical managerial leadership behaviors. Paper presented at Midwest Academy of Management $53^{\text {rd }}$ Annual Meeting, Grand Forks, ND.

Peterson T. O., \& Peterson, C. M. (2012). What managerial leadership behaviors do student managerial leaders need? An empirical study of student organizational members. Journal of Leadership Education, 11(1), 102-117. http://dx.doi.org/10.12806/V11/I1/RF6

Peterson, T. O., \& Van Fleet, D. D. (2003). Critical managerial leadership behaviors: An empirical study of crisis and stable environments. Paper presented at the Southern Management Association 2003 Annual Conference, Clearwater Beach, FL.

Peterson, T. O., \& Van Fleet, D. D. (2008). Tale of two situations: An empirical study of not-for-profit managerial leaders' behaviors. Public Performance \& Management Review, 31(4), 503-516. http://dx.doi.org/10.2753/PMR1530-9576310401 
Peterson, T. O., Beard, J. W., \& Van Fleet, D. D. (2012). The impact of situational factors on information systems (IS) managerial leader behaviors: What information system employees want. Journal of Business \& Leadership, 8, 54-68

Roberts, D. C. (2007). Deeper learning in leadership: Helping college students find the potential within. San Francisco, CA: Jossey-Bass.

Tukey, J. W. (1977). Exploratory data analysis. Reading, PA: Addison-Wesley.

Van Velsor, E., McCauley, C. D., \& Moxley, R. S. (1998). Our view of leadership development. In C. D. McCauley, R. S. Moxley, \& E. Van Velsor (Eds.), Handbook of leadership development (pp. 1-25). San Francisco, CA: Jossey-Bass.

Yukl, G. A., \& Nemeroff, W. F. (1979). Identification and measurement of specific categories of leadership behavior: A progress report. In J. G. Hunt \& L. L. Larson (Eds.), Crosscurrents in leadership (pp. 164-200). Carbondale, IL: Southern Illinois University Press.

Yukl, G. A., \& Van Fleet, D. D. (1982). Cross-situational, multi-method research on military leader effectiveness. Organizational Behavior and Human Performance, 30(1), 87-108. http://dx.doi.org/10.1016/0030-5073(82)90235-5

Yukl, G. A., Wall, S., \& Lepsinger, R. (1990). Preliminary report on validation of the management practices survey. In K. E. Clark \& M. B. Clark (Eds.), Measures of leadership (pp. 223-237). West Orange, NJ: Leadership Library of America.

\section{Appendix}

Below are 25 behaviors a student leader could exhibit on any given day. All of these behaviors are important in order to achieve the organization's purpose. First pick the ten (10) behaviors that you think are most critical for a student leader to achieve your organization's purpose. Next please rank from 1 (highest) to 10 (lowest) these ten (10) behaviors.

Student leader emphasizes the importance of organizational member's performance, tries to improve productivity, and tries to keep members working up to their ability.

Student leader is friendly, supportive, and considerate in his or her behavior toward organizational members and tries to be fair and objective.

Student leader stimulates enthusiasm among organizational members for the work and builds members confidence in their ability to perform assignments successfully.

Student leader provides praise and recognition to organizational members with effective performance, shows appreciation for their contributions, and makes sure the members get credit for their ideas and suggestions.

Student leader rewards effective organizational member performance with tangible benefits such as a more desirable assignment, better work schedule, or special opportunity. 
Student leader builds and maintains a strong effective team that recognizes the importance of shared purpose and mutual accountability.

Student leader consults with organizational members and otherwise allows them to influence his or her decisions.

Student leader delegates authority and responsibility to organizational members and allows them to determine how to do their work.

Student leader informs organizational members about their duties and responsibilities, specifies the rules and policies that must be observed, and lets members know what is expected of them.

Student leader emphasizes the importance of setting specific performance goals for each important aspect of the organizational member's job.

Student leader measures progress toward the performance goals and provides concrete feedback.

Student leader determines training needs for organizational members, and provides any necessary training and coaching.

Student leader keeps organizational members informed about developments that affect their work, including events in other student organizations or outside the organization, and decisions made by higher administration.

Student leader takes the initiative in proposing solutions to serious work-related problems and acts decisively to deal with such problems when a prompt solution is needed.

Student leader coordinates the work of organizational members, emphasizes the importance of coordination, and encourages members to coordinate their activities.

Student leader obtains for organizational members any necessary supplies, equipment, support services, or other resources needed to complete the work.

Student leader removes other obstacles that interfere with the work.

Student leader establishes contacts with other student groups and important people in the organization, persuades them to appreciate and support his or her student organization, and uses his or her influence to promote and defend the interests of the organization.

Student leader gets organizational members to be friendly with each other, cooperate with each other, and help each other.

Student leader restrains organizational members from arguing, encourages them to resolve conflicts in a constructive manner, and helps to settle conflicts and disagreements between the members.

Student leader disciplines an organizational member who shows consistently poor performance, violates a rule, or disobeys directions. 
Student leader plans the organization's future objectives and makes contingency plans for potential problems.

Student leader creates a clear and compelling direction for the student organization to pursue.

Student leader identifies and enforces the norms of the student organization.

Student leader has a presence about him or her that builds trust, commands attention, is authentic, and credible.

While this survey is anonymous, we would appreciate knowing a little about you to help us better understand the responses we obtain. Please complete the following items.

Check or fill-in as appropriate.

Age

$\square$ Male $\square$ Female

What is your current classification?

$\square$ Freshman $\square$ Sophomore $\square$ Junior $\square$ Senior

$\square$ Other Please specify

What is your major?

Which student organization are you completing this survey about?

\section{Copyright Disclaimer}

Copyright for this article is retained by the author(s), with first publication rights granted to the journal.

This is an open-access article distributed under the terms and conditions of the Creative Commons Attribution license (http://creativecommons.org/licenses/by/3.0/). 